Handboek schematherapie 


\section{Handboek schematherapie}

Theorie, praktijk en onderzoek

Onder redactie van

Michiel van Vreeswijk

Jenny Broersen

Marjon Nadort

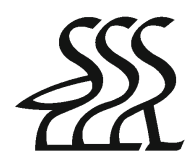

Bohn Stafleu van Loghum

Houten 2008 
(C) 2008 Bohn Stafleu van Loghum, onderdeel van Springer Uitgeverij

Alle rechten voorbehouden. Niets uit deze uitgave mag worden verveelvoudigd, opgeslagen in een geautomatiseerd gegevensbestand, of openbaar gemaakt, in enige vorm of op enige wijze, hetzij elektronisch, mechanisch, door fotokopieën of opnamen, hetzij op enige andere manier, zonder voorafgaande schriftelijke toestemming van de uitgever. Voor zover het maken van kopieën uit deze uitgave is toegestaan op grond van artikel 16b Auteurswet $1912 \mathrm{j}^{\mathrm{o}}$ het Besluit van 20 juni 1974, Stb. 351, zoals gewijzigd bij het Besluit van 23 augustus 1985, Stb. 471 en artikel 17 Auteurswet 1912, dient men de daarvoor wettelijk verschuldigde vergoedingen te voldoen aan de Stichting Reprorecht (Postbus 3051, 2130 KB Hoofddorp). Voor het overnemen van (een) gedeelte(n) uit deze uitgave in bloemlezingen, readers en andere compilatiewerken (artikel 16 Auteurswet 1912) dient men zich tot de uitgever te wenden.

Samensteller(s) en uitgever zijn zich volledig bewust van hun taak een betrouwbare uitgave te verzorgen. Niettemin kunnen zij geen aansprakelijkheid aanvaarden voor drukfouten en andere onjuistheden die eventueel in deze uitgave voorkomen.

ISBN 9789031353040

NUR 777

Ontwerp omslag: Nanja Toebak, 's-Hertogenbosch

Ontwerp binnenwerk: TEFF (www.teff.nl)

Automatische opmaak: Prepress, Zeist

Bohn Stafleu van Loghum

Het Spoor 2

Postbus 246

3990 GA Houten

www.bsl.nl 


\section{Inhoud}

Voorwoord

DEEL 1

INLEIDING

$1 \quad$ Algemene inleiding

M.F. van Vreeswijk, J. Broersen en M. Nadort

2 Een beknopte geschiedenis van schematherapie

A. Arntz

3 Theoretisch model: schema's, copingstrategieën en modi

H. van Genderen, M. Rijkerboer en A. Arntz

DEEL 2

DIAGNOSTIEK EN INDICATIESTELLING

$4 \quad$ Indicatiestelling voor schematherapie

A. Weertman en H. de Saeger

5 Gebruik van experiëntiële technieken voor diagnostiek

A. Weertman 
6 Het gebruik van vragenlijsten

A. Sheffield en G. Waller

7 Casusconceptualisatie in schematherapie

H. van Genderen

DEEL 3

BEHANDELING

8 Technieken in schematherapie

M.F. van Vreeswijk, J. Broersen, J. Giesen-Bloo en S. Hayen

9 Schematherapie bij adolescenten

M.T. Geerdink, E.J. Jongman en H.A. Scholing

10 Schematherapie bij persoonlijkheidsproblematiek en verslaving

T. Kersten

11 Schematherapie voor Forensische Patiënten

D. Bernstein, M. de Vos en A. Arntz

12 Individuele schematherapie: de praktijk bij volwassenen

N.A. van den Kieboom en D.J.L. Jonker

13 Schematherapie bij relatieproblematiek

T.W.A. Atkinson

14 Schematherapie in een klinische (groeps)setting E. Muste

15 Schematherapie in groepen; een protocollaire behandeling 
16 Schematherapie in een psychodynamische groep

H. Aalders, A. Boerwinkel en J. van Dijk

17 Effect van meten is weten: therapieresultaten en therapeutische relatie

M.F. van Vreeswijk, J. Broersen en Ph. Spinhoven

DEEL 4

OPLEIDING

18 Opleiding en registratie tot schematherapeut

215

M. Nadort en H. van Genderen

19 Cursussen op het gebied van schematherapie

M. Nadort en H. van Genderen

20 Supervisie bij schematherapie

M. Nadort en H. van Genderen

\section{DEEL 5}

ONDERZOEK

21 Effectiviteitsstudies

L. Bamelis, J. Giesen-Bloo, D. Bernstein en A. Arntz

22 Experimentele studies naar schemamodi

23 Experimentele studies naar schema's

S.H. Sieswerda

24 Validatie schemavragenlijst 
25 Validatie van de Schema Mode Inventory (SMI)

J. Lobbestael

DEEL 6

ORGANISATIE EN MANAGEMENT

26 Implementatie van schematherapie in ggz-instellingen

M. Nadort

27 Implementatie van schematherapie in Forensisch Psychiatrisch Centrum de Rooyse Wissel

T. Kersten en L. van de Vis

28 Kosteneffectiviteit van schematherapie

A.D.I. van Asselt en J.H. Giesen-Bloo

29 Voorlichting over schematherapie

M.F. van Vreeswijk, M. Nadort en J. Broersen

De auteurs

Register 


\section{Voorwoord}

'Hoe kan ik zwijgen van mijn oud verleden, terwijl ik, op het oog zo blij

en simpel, in mijn ziel ondraaglijk weet heb

van zoveel sterren boven mij?

Ik, kind met gretige, verbaasde ogen,

ik - bundel aderen, verkleefd

met rode vliezen en met parelbogen -

weet dat ik eeuwig heb geleefd.

Op mijn eonenlange reis langs elke

planeet waar pijn en God bestaan

heb ik daar in de hete ruimte telkens

weer meer begrip van opgedaan.

Het valt niet mee mijn wonder-zinloos branden

in toom te houden, vleugels laag,

omdat de adem van de sterren anders,

het aards geluk misschien verjaagt.

Nabokov, 13-1-1923 (Gedichten, 2002)

Schematherapie is voor patiënten met ernstige problemen. Vaak zijn dit langdurige klachten die zich afspelen op vele levensgebieden. Verandering van deze problematiek vergt meestal een veelheid van en gevarieerdheid aan verschillende technieken. Daarnaast kunnen deze technieken alleen maar plaatsvinden binnen een goede therapeutische relatie. De kracht van schematherapie ligt naar ons idee in een goede combinatie van beide.

De auteurs van de hoofdstukken in dit handboek willen wij danken voor hun inzet, deskundigheid en de bereidheid om hun kennis met vakgenoten te delen. 
Wij hopen dat door dit boek uw belangstelling en enthousiasme voor schematherapie zal toenemen.

De redactie:

Michiel van Vreeswijk

Jenny Broersen

Marjon Nadort 